\title{
Proximate composition and microbiological study of five marine fish species consumed in Gabon
}

\section{Alain Serges ONDO-AZI ${ }^{1 *}$, Brice Serge KUMULUNGUI ${ }^{1}$, Ludovic MEWONO ${ }^{2}$ and Armel MBINA KOUMBA ${ }^{1}$ and Crépin ELLA MISSANG ${ }^{1,3}$}

\author{
${ }^{1}$ Unité de Recherche Agrobiologie, Université des Sciences et Techniques de Masuku, B.P. 941 Masuku Franceville \\ Gabon. \\ ${ }^{2}$ Laboratoire d'Immunologie, de Microbiologie appliquée et d'Hygiène, Ecole Normale Supérieure, B.P. \\ 440 Libreville Gabon. \\ ${ }^{3}$ Institut de Recherche Technologique, CENAREST, B.P. 14.070, Libreville, Gabon.
}

Accepted 4 June, 2013

\begin{abstract}
The aim of the current study was to determine proximate composition (protein, lipid, ash and moisture), energy and microbiological spoilage in five fish species. The chemical analysis revealed that the protein content of Pseudotolithus typus was $19.19 \%$, Pomadasys peroteti $16.05 \%$, Galeoides decadactylus $17.15 \%$, Carassius auratus $20.78 \%$ and Pimelodus grosskopfii $18.57 \%$ of the fresh weight, respectively. The lipid content, the ash, and carbohydrate ranged from 0.46 to $1.76,1.01$ to 1.40 and 0.20 to $\mathbf{0 . 4 9 \%}$ of the fresh weight correspondingly. Microbiological analysis showed that the Total Viable Count (TVC) varied between 5.20 and $8.42 \mathrm{LogUFC} / \mathrm{g}$. The results obtained on TVC were not within the acceptable limits set by the International Commission on Microbiological Specification for Foods. Staphylococcus sp. bacteria were observed in all five species and fecal coliforms in Carassius auratus and Pimelodus grosskopfii only. The bacteria isolated on each of the five fish species included Staphylococcus aureus, Staphylococcus xylosus, Enterobacter agglomerans and one unidentified species. However, fungi were not found in these five samples.
\end{abstract}

Key words: Franceville, Gabon, proximate composition, microbiological quality, fish species.

\section{INTRODUCTION}

Fish is known to be highly nutritious and excellent source of animal proteins which is consumed by a largef percentage of populace of Gabon because of its availability and palatability (Foran et al., 2005; Sutharshiny and Sivashanthini, 2011a). Fish is also, a vitamin and mineral rich food for young and old consumers (Edem, 2009; Koffi-Nevry et al., 2011). The nutritional characteristics of fish and fishery products are of vital interest to consumers. However, the consumption of fish has been linked to health benefits such as reduced risk of coronary heart disease and maintenance of a healthy body (Arannilewa et al., 2005). Polyunsaturatted fatty acids from fish have been reported to have preventive and/or curative effects for several diseases including arterial hypertension (Turkmen et al., 2005), cancers and inflammatory diseases (Marchioli, 2001).

Fish meat contains significantly low lipids and high water compared to that of beef or chicken and is favoured over other white or red meats (Nestel, 2000). Fish products contain most important nutritional components 
Table 1. List of fish samples collected in Franceville for our study.

\begin{tabular}{llll}
\hline Local name & Common name & Scientific name & Family \\
\hline Capitaine & Croaker & Pseudotolithus typus & Moronidae, Polynemidae \\
Dorade grise & Black sea bream & Pomadasys peroteti & Sparidae, Haemulidae \\
Bar & Threadfins (Sea bass) & Galeoides decadactylus & Lethrinidae, Sciaenidae \\
Poisson rouge & Goldfish & Carassius auratus & Cyprinidae \\
Mâchoiron & & Pimelodus grosskopfii & Bragidae, Pimelodidae \\
\hline
\end{tabular}

and serves as source of energy for human beings (KoffiNevry, 2009; Surtharshiny and Sivashanthini, 2011a). However, these values vary considerably within and between species, size, sexual condition, feeding season and physical activity (Chandrashekar and Deosthale, 1993). Moreover, measurements of the some proximate profiles such as protein, lipids and moisture contents are often necessary to ensure that they meet the requirements of food regulations and commercial specifications (Waterman, 2000; Tawfik, 2009; Surtharshiny and Sivashanthini, 2011a). However, all these positive interests can be decrease by microbial activities.

In fact, tropical areas are not suitable for conservation methods and fish consumption is a problem since it is a highly perishable product. In urban areas, freezing is the most used method but the cold supply chain often not guaranteed. This study was carried out to determine proximate composition (including protein, lipid, ash, carbohydrate and moisture), the caloric value and microbial impact on five fish species collected from Franceville market.

\section{MATERIALS AND METHODS}

\section{Source of samples}

All fishes were purchased from the local market in the Franceville city, South-East of Gabon. Five fish species were included in this study (Table 1) during 2010. These species are among the most commonly consummated in Gabon. Five kilograms (12 to 18 entire fishes) of each fish species collected were immediately dipped in ice, kept and transported in sterile polystyrene boxes to sustain freshness. Then, samples convoyed to the laboratory for analysis.

\section{Proximate analysis}

The protein content was determined by estimation of the total Nitrogen by Kjeldahl method and protein content was calculated by multiplying total nitrogen by 6.25 factor (AOAC, 2000) while the moisture content of the pulp was determined after drying at $103^{\circ} \mathrm{C}$ for $24 \mathrm{~h}$. The percentage of ash was determined by ignition in a muffle furnace at $550^{\circ} \mathrm{C}$ as described by Pearson (1976), while lipid content in pulp was extracted using hexane in a soxhlet extractor as described by AOAC (2000). The method of Dubois et al. (1956) was used to determine the carbohydrate content of the dry sample. The energetic density was calculated using the specific coefficients of Atwater and Rosa (1899). All the experients were made in triplicate, the results were expressed on fresh weight and mean values were given.

\section{Microbiological analysis}

The muscles of the fishes were cut aseptically using sterile forceps and scalpels and five grams $(5 \mathrm{~g})$ aseptically weighted into conical flask containing $45 \mathrm{ml}$ of sterile deionised water. The contents were then transferred into a sterile mortar and homogenate into a watery paste all within $40 \mathrm{~min}$. Serial dilutions of the samples were used for microbial enumeration with the following media: Standard Plate count Agar for Total Viable Counts (TVC), Sabouraud Chloramphenicol (for fungi), Chapman (for staphylococci) and Mac Conkey (for total and fecal coliforms) medium for bacteria specifications. Proportions $(0.1 \mathrm{ml})$ of appropriate dilution were spread plated. The standard plate count method described by Coulin et al. (2006) was used to determine the total viable cell count. On each Petri dish, colonies were inventoried before culturing. Pure cultures of the isolates were Gram-stained, while the cell morphology was examined by phase contrast microscopy. Fungi were isolated on the sabouraud chloramphenicol (SC) and potatoes dextrin agar (PDA) media. After incubation at $37^{\circ} \mathrm{C}$, the Petri dishes were examined in the laboratory.

\section{Statistical analyses}

The Statistical Package for Social Science (SPSS version 16.0) was used. Data analysis involved one-way Analysis of Variance (ANOVA). The mean differences were determined using Duncan's Multiple Range Test. A significant difference was established at $p<$ 0.05 .

\section{RESULTS}

\section{Proximate composition of the samples}

Proximate composition included moisture, lipid, protein, ash and carbohydrate contents, and caloric value of the samples is presented in Table 2. The moisture content ranged from 74.46 to $78.50 \%$ for $C$. auratus and $G$. decadactylus, respectively. Crude ash ranged from $1.01 \%$ in $P$. peroteti to $1.40 \%$ in C. auratus. Carbohydrates composition estimated in the samples analysed varied between $0.20 \% \quad(P$. typus) and $0.49 \% \quad(P$. grosskopfii). The crude protein content ranged from 
Table 2. Chemical and nutritional parameters of fishes collected from Gabon (mean percentage \pm SD).

\begin{tabular}{lcccccc}
\hline \multirow{2}{*}{ Species } & \multicolumn{7}{c}{ Parameter $^{\star *}$} \\
\cline { 2 - 6 } & Moisture & Lipid & Crude protein & Ash & Carbohydrate & Energy \\
\hline Pseudotolithus typus & $77.39 \pm 0.16^{\mathrm{b}}$ & $0.47 \pm 0.00^{\mathrm{a}}$ & $19.19 \pm 1.19^{\mathrm{d}}$ & $1.15 \pm 0.15^{\mathrm{ab}}$ & $0.20 \pm 0.00^{\mathrm{a}}$ & $81.79 \pm 0.64^{\mathrm{b}}$ \\
Pomadasys peroteti & $78.50 \pm 0.14^{\mathrm{c}}$ & $0.67 \pm 0.03^{\mathrm{b}}$ & $16.05 \pm 0.20^{\mathrm{a}}$ & $1.01 \pm 0.14^{\mathrm{a}}$ & $0.44 \pm 0.02^{\mathrm{b}}$ & $71.99 \pm 1.15^{\mathrm{a}}$ \\
Galeoides decadactylus & $78.46 \pm 0.20^{\mathrm{c}}$ & $1.50 \pm 0.17^{\mathrm{c}}$ & $17.15 \pm 0.19^{\mathrm{b}}$ & $1.10 \pm 0.07^{\mathrm{ab}}$ & $0.29 \pm 0.04^{\mathrm{a}}$ & $83.26 \pm 2.45^{\mathrm{b}}$ \\
Carassius auratus & $74.36 \pm 0.23^{\mathrm{a}}$ & $1.76 \pm 0.05^{\mathrm{d}}$ & $20.78 \pm 0.37^{\mathrm{e}}$ & $1.40 \pm 0.07^{\mathrm{c}}$ & $0.41 \pm 0.10^{\mathrm{b}}$ & $100.6 \pm 1.35^{\mathrm{c}}$ \\
Pimelodus grosskopfii & $77.29 \pm 0.33^{\mathrm{b}}$ & $0.46 \pm 0.03^{\mathrm{a}}$ & $18.57 \pm 0.20^{\mathrm{c}}$ & $1.23 \pm 0.08^{\mathrm{bc}}$ & $0.49 \pm 0.07^{\mathrm{b}}$ & $80.38 \pm 1.35^{\mathrm{b}}$ \\
\hline
\end{tabular}

*Means within a row followed by different letters are significantly different $(\mathrm{p}<0.05)$; ${ }^{* *}$ expressed in $\mathrm{kcal}$ and other parameters in $\mathrm{g}$.

Table 3. Bacterial burden of fish samples collected from Gabon.

\begin{tabular}{lccc}
\hline Species & TVC (Log CFU) & Coliforms $^{* *}$ (Log CFU) & Staphylococcus (Log CFU) \\
\hline Pseudotolithus typus & $8.42^{\mathrm{b}}$ & - & $5.33^{\mathrm{b}}$ \\
Pomadasys peroteti & $5.64^{\mathrm{a}}$ & - & $5.43^{\mathrm{b}}$ \\
Galeoides decadactylus & $7.54^{\mathrm{b}}$ & - & $4.90^{\mathrm{ab}}$ \\
Carassius auratus & $5.20^{\mathrm{a}}$ & $3.08^{\mathrm{a}}$ & $4.20^{\mathrm{a}}$ \\
Pimelodus grosskopfii & $5.23^{\mathrm{a}}$ & $4.15^{\mathrm{b}}$ & $4.51^{\mathrm{a}}$ \\
\hline
\end{tabular}

${ }^{*}$ Means within a row followed by different letters are significantly different $(p<0.05) ;{ }^{* *}$ : - no growth.

Table 4. Microorganisms isolated from some fish species collected from Gabon.

\begin{tabular}{|c|c|c|c|c|c|c|}
\hline \multirow[b]{2}{*}{ Organism } & \multirow[b]{2}{*}{ Characteristics } & \multicolumn{5}{|c|}{ Fish species } \\
\hline & & $\begin{array}{c}P . \\
\text { typus }\end{array}$ & $\begin{array}{c}P . \\
\text { peroteti }\end{array}$ & $\begin{array}{c}\text { G. } \\
\text { decadactylus }\end{array}$ & $\begin{array}{c}\text { C. } \\
\text { auratus }\end{array}$ & P. grosskopfii \\
\hline S. aureus & Raised, white, cocci, $\mathrm{G}+$, regular & $x$ & $\times$ & $x$ & $x$ & $x$ \\
\hline S. xylosus & $\begin{array}{l}\text { Raised, yellow, cocci, } \mathrm{G}_{+} \text {, regular, } \\
\text { opaque }\end{array}$ & $x$ & $x$ & $x$ & $x$ & $x$ \\
\hline E. agglomerans & Raised, white, stick, G-, irregular & - & - & - & $x$ & $x$ \\
\hline Not indentified species & Raised, white, stick, G-, regular & - & - & - & $\times$ & $\times$ \\
\hline
\end{tabular}

Note: ×, Presence; -, absence; G+, Gram+; G-, Gram-.

$16.05 \%$ ( $P$. peroteti) to $20.78 \%$ (C. auratus). Caloric value varied from $71.99(P$. peroteti) to $100.6 \mathrm{kcal} / 100 \mathrm{~g}$ (C. auratus). The lipid content was found to be between 0.46 to $1.76 \%$ in this study.

\section{Microbiological analysis}

The microbiological status of the samples is summarized in Table 3. This table shows that total viable count (TVC) of the five fish species varied from 5.20 to 8.42 Log $\mathrm{CFU} / \mathrm{g}$. In three species ( $P$. typus, $P$. peroteti and $G$. decadactylus), coliforms were absent but found in the two others species as $3.08 \mathrm{Log} \mathrm{CFU} / \mathrm{g}$ for $C$. auratus and $4.15 \mathrm{Log} \mathrm{CFU} / \mathrm{g}$ for $P$. grosskopfii. On fungal specific media, none microbial growth was observed for the five samples. Table 4 shows the microbial isolates obtained from several fish species samples analysed. Staphylococcus aureus and Staphylococcus xylosus were found on all fish samples; Enterobacter agglomerans and an unidentified species on both of $C$. auratus and P. Grosskopfii.

\section{DISCUSSION}

The growing urban population in South Sahara Africa countries calls for increasing attention on food safety and quality. In Gabon, fish is among the most preferred food product. In the present study, we have investigated the 
five most consumed fish species in Franceville, Gabon. The proximate composition, caloric value and microbial safety were examined. The values obtained on proximate composition (moisture, protein, lipid, ash and carbohydrate contents) of the five fish samples analysed in this study were in-line with those reported elsewhere (Tawfi, 2009; Pirestani, 2010; Nurnadia et al., 2011). For moisture content, the highest contents were found on $P$. peroteti $(78.50 \%)$ and $G$. decadactylus $(78.46 \%)$ and the lowest value was obtained with $C$. auratus $(74.48 \%)$. Based on the lipid content, $P$. typus, $P$. peroteti and $P$. grosskopfii were distinguished as lean fish, where the lipid content was lower than $1 \%$ for fresh weight (Tawfik, 2009; Sutharshiny and Sivashanthini, 2011b), while G. decadactylus and $C$. auratus were classified as semi-lean (half-lean) fish. In addition, we found that the species ( $P$. peroteti, $P$. typus and $P$. grosskopfii) which had low fat content had the highest water content as reported by Osman et al. (2001) As a consequence, their flesh is withering in colour. On the five fish species, crude proteins had high values. This result is in-line with the reports of other authors (Stefens, 2006; Elagba et al., 2010), that protein forms the largest quantity of dry matter in fish sample. Likewise, these high values obtained may explain the important living resources of dietary protein as other sea fish (Zuraini et al., 2006; Elagba et al., 2010).

Crude ash content varied little between species and was low in comparison with the finding of Pirestani (2010) and Nurnadia et al. (2011), who found values of up to $3.3 \%$. Caloric value calculated for the five fish species was dominated by lipid and protein. The lipid content showed a large variation between lean and semi-lean fishes. The protein content showed low variation between species. The nutritional proprieties of the five fish samples are acceptable, showed significant differences $(P>0.05)$ between fish species. Regarding proximate composition, values presented in this study are near to those found by others (Tawfik, 2009; Nurnadia et al., 2011; Barua et al., 2012) and specially, for specie $P$. typus (Osibona, 2011). Microbiological count of the $C$. auratus, $P$. grossopfii and $P$. peroteti species was lower than for $G$. decadactylus and $P$. typus. Results recorded on the three firsts species indicated values nearer to the findings of Ouattara (1986) who observed 6.11 Log $\mathrm{CFU} / \mathrm{g}$. The higher values observed on $\mathrm{G}$. decadactylus and $P$. typus was similar to results reported by Kovacevic (1970). All the values obtained in microbiological analysis of the fish samples were higher than the acceptable International Commission on Microbiological Specification for Foods (ICMSF) and French Norms (FN) limits. In fact, ICMSF and FN have a limit of $4.70 \mathrm{Log}$ CFU/g for frozen fishes. The analysis on specific medium showed that the predominant microorganisms were staphylococci and coliforms; fungi were not detected. The coliforms were found on C. auratus and P. peroteti; Seydi et al. (1992) observed 2.8 Log CFU/g on fish sample. Staphylococci were present on all the fish samples with values ranging from 4.20 to $5.43 \mathrm{Log}$ CFU/g. These values were higher than findings from other authors (Bernadac et al., 1985; Ouattara, 1986; Ndiaye, 1998) and opposite to Bernadac et al. (1985) who reported that fish samples were free from staphylococci.

The inventory of microorganisms found on the five samples reveals the presence of four bacterial species: $S$. aureus, S. xylosus, E. agglomerans and one unidentified species. So, some strains of $S$. aureus are capable of producing a highly heat-stable protein toxin that causes illness in humans and $S$. xylosus is implicated in fish degradation (Jeantet et al., 2006).

E. agglomerans belongs in the family Enterobacteraceae. They have been associated with nosocomial outbreaks, and are considered opportunistic pathogens. This study shows that the preferential fish species consumed in Franceville presented a good nutritional composition. The high proteins content confirms that these species are good animal proteins sources; they are particularly consigned for the children growing stages. The caloric value confirms their energetic plus value. However, microbial results show large count; these microbial qualities are not acceptable. The bacterial microorganisms isolated and identified can disrupt human health.

\section{REFERENCES}

AOAC (2000). Official Methods of Analysis 17th ed. W. Hortuntwed (Ed), Association of Official Analytical Chemists. Washington.

Arannilewa ST, Salawu SO, Sorungbe AA, Aubrey GD (2005). Effect of frozen period on the chemical, microbiological and sensory quality of frozen tilapia fish (Sarotherodun galiaenus). Afr. J. Biotechnol. 4:852855.

Atwater W, Rosa EA (1899). A new respiratory calorimeter and experiments on the conservation of energy in human body. II. Phys. Rev. 9:214-251.

Bernadac M, Scheid A, Hugon B (1985). Aptitude à la conservation et contrôle microbiologique de poisons congelés, conditionnés sous pellicule plastique en atmosphère compensée. R.T.V.A. 208:25-34.

Chandrashekar K, Deasthale YG (1993). Proximate composition, amino acid, mineral, and trace element content of the edible muscle of 20 Indian fish species. J. Food Compost. Anal. 6:195-200.

Coulin P, Faraz Z, Assanvo J, Spillmann H, Puhan Z (2006). Characterisation of the microflora of attieke, a fermented cassava product during traditional small-scale preparation. Int. J. Food Microbiol. 106:131-136.

Dubois M, Gilles KA, Hamilton JK, Rebers PA, Smith F (1956). Colorimetric method for determination of sugars and related substances. Anal. Chem. 28:350-356.

Edem DO (2009). Vitamin A: A review. Asian J. Clin. Nutr. 1: 65-82.

Foran JA, Carpenter DO, Hamilton MC, Knuth BA, Schwager SJ (2005). Risk- based consumption advice for farmed Atlantic and wild pacific salmon contaminated with dioxins and dioxin- like compounds. Environ. Health Perspect. 33:552-556.

Jeantet R, Croguennec T, Schuck P, Brilé G (2006). Science des aliments. Stabilisation biologique et physicochimie. Tec \& Doc (Ed). Lavoisier. Paris France. pp. 59-94.

Koffi-Nevry R, Ouina TST, Koussemon M, Brou BK (2011). Chemical composition and lactic microflora of Adjuevan, a traditional Ivorian 
fermented fish condition. Pak. J. Nutr. 10:332-337.

Kovacevic M (1970). Quelques renseignements sur la microbiologie alimentaire : Objectifs et Méthodes. PNUD/FAO. 1-12.

Marchioli R (2001). Efficacy of $n-3$ polyunsaturated fatty acids after myocardial infarction: results of GISSI-Prevenzione trial. Gruppo Italiano per lo Studio della Sopravvivenza nell'Infarto Miocardico. Lipids 36 Suppl:S119-26.

Ndiaye A (1998). Contribution à l'évolution de la qualité bactériologique des produits de la pêche destinés à l'exportation en 1996 et 1997. Thèse de Médecine Vétérinaire, Dakar. pp. 73.

Nestel PJN (2000). Fish oil and cardiovascular disease: lipids and arterial function. Am. J. Clin. Nutr. 71:228-231.

Nurnadia AA, Azrina A, Amin I (2011). Proximate composition and energetic value of selected marine fish and shellfish from the west coast of Peninsular Malaysia. Int. Food Res. J. 18:137-148.

Osman H, Suriah AR, Law EC (2001). Fatty composition and cholesterol content of selected marine fish in Malaysian water. Food Chem. 73:55-60.

Ouattara P (1986). Etude de la qualité microbiologique des poissons congelés. Thèse de Médecine Vétérinaire Dakar. 20.

Pearson AD (1976). The Chemical analysis of food. 7th Ed. Edinburg: Churchill, Livingstone. pp. 422-511.
Pirestani S (2010). Lipid, cholesterol and fatty acid profile of some commercially important fish species from South Caspian. J. Food Biochem. 34(4):886-895.

Seydi M, Pangui A, Azibe B (1992). Qualité hygiénique des filets de poissons congelés produits au Sénégal. Rev. Microbiol. Hyg. Aliment. 9(4):12-17.

Sutharshiny S, Sivashanthini K (2011a). Total lipid and cholesterol content in the flesh of the five important commercial fishes from around Jaffna Peninsula, Sri Lanka. Int. J. Biol. Chem. 6: 161-169.

Sutharshiny S, Sivashanthini K (2011b). Proximate composition of three species of Scomberoides fish from Sri Lankan Waters. Asian J. Clin. Nutr. 3(3):103-111.

Tawfik MS (2009). Proximate composition and fatty acids profiles in most common available fish species in Saudi market. Asian J. Clin. Nutr. 1(1):50-57.

Turkmen A, Aro T, Nurmi T, Kallio H (2005). Heavy metals in three commercially valuable fish species from Iskenderun Bay. Northern East Mediterranean Sea, Turkey. Food Chem. 91:167-172.

Waterman JJ (2000). Composition and Quality of Fish. Torry Research Statation. Edinburgh. 